\title{
Isolation, Characterization and Evaluation of Endophytic Fractions of Centella asiatica Linn. (Leaves) for Invitro Antioxidant Activity
}

\author{
R. A. Shastry ${ }^{1 *}$, P. V. Habbu ${ }^{1}$, D. M. Smita ${ }^{1}$, Sudhir R. Iliger ${ }^{2}$ and V. H. Kulkarni ${ }^{2}$ \\ 'Department of Pharmacognosy, Post Graduate Studies and Research Center, S.E.T's College of \\ Pharmacy, S. R. Nagar, Dharwad - 580002, Karnataka, India; rashastri123@gmail.com \\ 2Department of Pharmaceutics, S.E.T's College of Pharmacy, S.R. Nagar, \\ Dharwad - 580002, Karnataka, India
}

\begin{abstract}
In the present investigation, we have carried out the isolation of fungal endophytes from Centella asiatica Linn leaves followed by fermentation and extraction of fungal endophytes with non-polar solvents such as chloroform, ethyl acetate and n-butanol. Preliminary phytochemical investigation of endophytic crude fractions of leaves were also determined to detect the presence of primary and secondary metabolites followed by invitro free radical scavenging activity by reducing power, DPPH and hydroxyl radical assay. The chloroform fungal endophytic fractions were subjected to column chromatography by gradient elution technique for isolation of possible secondary metabolite. Reducing power of endophytic extracts of C. asiatica Leaf (CAL-1) $(50-450 \mu \mathrm{g} / \mathrm{ml})$ increased with increase in concentration. Reaction with DPPH radicals of CAL-1 showed good scavenging activity. The $\mathrm{IC}_{50}$ values for Ascorbic acid, chloroform extract, ethyl acetate extract and $\mathrm{n}$ - butanol extract were found to be $30.33 \mu \mathrm{g} / \mathrm{ml}, 66.58 \mu \mathrm{g} / \mathrm{ml}, 79.33 \mu \mathrm{g} / \mathrm{ml}$ and $96.39 \mu \mathrm{g} / \mathrm{ml}$ respectively. In hydroxyl radical assay, The $\mathrm{IC}_{50}$ values for mannitol, chloroform extract, ethyl acetate extract and $\mathrm{n}$ - butanol extract were found to be $121.06 \mu \mathrm{g} /$ $\mathrm{ml}, 141.21 \mu \mathrm{g} / \mathrm{ml}, 181.80 \mu \mathrm{g} / \mathrm{ml}$ and $189.90 \mu \mathrm{g} / \mathrm{ml}$ respectively. The endophytic crude fractions of ethyl acetate exhibited potent antioxidant activity as compared to other fractions. Hence, ethyl acetate fungal endophytic fractions of Centella asiatica Linn leaves can be employed as a potential antioxidant in the prevention of oxidative stress caused by the free radicals.
\end{abstract}

Keywords: Antioxidant, Centella asiatica, Column Chromatography, Endophyte

\section{Introduction}

Endophytes are the micro-organisms (fungi/bacteria) that live in the host tissue of plants, without causing harmful effects. Endophytes are capable of producing novel metabolites which may/may not be present in the

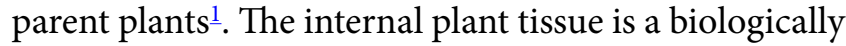
complex and distinct microhabitat within the terrestrial microsystem because of its varying content of alkaloids, terpenoids, steroids and aromatic compounds. Thus, healthy plant tissues represent an untapped reservoir of novel endophytic microorganisms producing bioactive metabolites. Because they are relatively unstudied, much attention is now being paid to endophytic biodiversity for their chemistry and bioactivity. Endophytic habitat appears to provide a protective environment that helps potentially exploitable bacteria/ fungi with reduced competition from the indigenous

${ }^{*}$ Author for correspondence 
microbial populations. Endophytic bacterial and fungal diversity has been extensively screened for antibacterial ${ }^{2}$, cytotoxic agents, as antioxidants ${ }^{3}$ antidiabetic and anti-immunosuppressive compounds ${ }^{4}$. Further, endophytic communities have been isolated from the roots of Panax ginseng with their potential antifungal activity against pathogens ${ }^{\underline{5}}$.

Centella asiatica (L) Urb (Apiaceae) is an ethnomedicinal plant, native to India, Madagascar, Sri Lanka, China, Indonesia, Australia and South Africa. It is a profusely branched prostrate herb, well known medicine to promote intelligence. The major chemical constituents found in the plant are triterpenoids ${ }^{6}$, vallarine, asiaticoside, sitosterol, tannin, oxy asiaticoside. Bioactive metabolites were isolated from endophytic fungus Penicillium sp. from Centella asiatica ${ }^{7}$. A new fungal species, named Echinosphaeria macrospora, teleomorph of Vermiculariopsiella endophytica, was discovered from the stems of $C$. asiatica ${ }^{8}$, Chaetomium globosum a fungal species was isolated within healthy leaves of C. asiatica collected from the Malnad region (Southern India) ${ }^{9}$. Inoculation of the growth-promoting endophytic fungus Piriformospora indica to roots of C. asiatica in vitro cultures resulted in the rapid enhancement of root and shoot biomass of the host plant and an increase in asiaticoside production in leaves $\frac{10}{}$, Pantoea agglomerans AR-PSBH2, an endophytic bacterium associated with C. asiatica, has shown high antioxidant potential $\underline{11}$.

In-vitro studies were conducted on the impact of endophytic bacteria isolated from Centella asiatica on the disease incidence caused by the hemibiotrophic fungus Colletotrichum higginsianum ${ }^{12}$, two endophytic fungi Aspergillus oryzae CeR1 and Colletotrichum gloeosporioides MKL1 were isolated from C. asiatica and $M$. koengii respectively which were characterized morphologically and by using rDNA- internal transcribed spacer. The total antioxidant power and free radical scavenging activity of the fungal extracts was estimated using the total phenolic content and 2, 2-diphenyl-1-picrylhydrazyl (DPPH) free radical assay along with the flavonoids and alkaloids content. The DPPH free radical assay showed that the ethanolic extract of endophytic fungi Aspergillus oryzae CeR1 had higher radical scavenging activity than Colletotrichum gloeosporioides MKL1 13 .

The antimicrobial potential of 6 endophytic fungi was isolated from leaves of Centella asiatica plant. The endophytes were isolated by using two different mycological media namely Potato Dextrose Agar (PDA), and Malt Extract Agar (MEA). Maximum endophyte was isolated in PDA. The ethyl acetate extract of endophytic fungi showed growth inhibition on atleast one pathogenic bacteria Klebsiella sp., Staphylococcussp., Pseudomonas sp., Salmonella sp., Proteus sp., Shigella sp., Serratia sp. But the activity against fungal pathogen was very low compare to bacteria. The Minimum Inhibitory Concentration (MIC) values for the extracts ranged from $50.6 \mu \mathrm{g} / \mathrm{ml}$ to $274.6 \mu \mathrm{g} / \mathrm{ml}$. Among all isolated endophytic fungi the fungus which has the highest positive antimicrobial activity was identified as Penicillium sp. by $18 \mathrm{~S}$ ribosome RNA sequence analysis $\stackrel{14}{ }$.

The effect of an aqueous Centella asiatica extracts $(100,200$ and $300 \mathrm{mg} / \mathrm{kg}$ for 21 days) was evaluated in intra-cerebroventricular (i.c.v.) streptozotocin (STZ)induced cognitive impairment and oxidative stress in rats. The rats treated with CA showed a dose-dependent increase in cognitive behaviour in passive avoidance and elevated plus-maze paradigms. A significant decrease in MDA and an increase in glutathione and catalase levels were observed only in rats treated with 200 and $300 \mathrm{mg} / \mathrm{kg} \mathrm{CA} \stackrel{15}{ }$.

The potential efficacy of Centella asiatica (CA) extracts was evaluated in rats in preventing the cognitive deficits, as well as the oxidative stress. Neuroprotection by CA was further supported by the phosphorylation of Cyclic AMP Response Element Binding (CREB) protein by an increase in both a neuroblastoma cell line expressing amyloid beta 1-42 (A beta) and in rat embryonic cortical primary cell culture ${ }^{16}$.

Oral treatment with $50 \mathrm{mg} / \mathrm{kg} /$ day of crude methanol extract of CA for 14 days significantly increased the anti-oxidant enzymes, like superoxide dismutase (SOD), catalase and glutathione peroxidase (GSHPx) in lymphoma-bearing mice, the anti-oxidants like glutathione (GSH) and ascorbic acid was decreased in the animals ${ }^{17}$. Community structures of endophytic actinobacteria was assessed from medicinal plant Centella asiatica based on a metagenomic approach 
using Polymerase Chain Reaction-Denaturing Gradient Gel Electrophoresis (PCR-DGGE) of 16S rRNA gene ${ }^{18}$.

Characterization of bacterial endophytes associated with Centella asiatica was carried out and screened for their antifungal activity using well diffused assay. The ability of the methanolic extracts of endophytic bacteria and host plant to inhibit and cause structural deformities in pathogenic fungal growth was evaluated using scanning electron microscope. The effect of endophytic methanolic extracts revealed considerable morphological alterations on the structures of pathogenic fungal hyphae and sclerotia. Endophytic Bacillus subtilis B showed prominent antifungal activity causing morphological distortion in the fungal morphology offering scope for exploration as alternative antifungal agent $\frac{19}{}$.

The primary active constituents of CA are saponins (triterpenoids), which include asiaticosides, in which a trisaccharide moiety is linked to the aglycone asiatic acid, madecassoside and madasiatic acid. These triterpene saponins and their sapogenins are mainly responsible for the wound healing and vascular effects by inhibiting the production of collagen at the wounded site. Other components isolated from $\mathrm{CA}$, such as brahmoside and brahminoside, may be responsible for CNS and uterorelaxant actions, but are yet to be confirmed by clinical studies. Crude extracts containing glycosides isothankuniside and thankuniside showed antifertility action in mice ${ }^{20}$. However, there is no scientific proof justifying the traditional use of Centella asiatica leaves from endophytic community to manage oxidative stress which is caused by the free radicals. Hence, the present work was undertaken to isolate, characterize and to evaluate its antioxidant effect in invitro experimental models.

\section{Materials and Methods}

\subsection{Collection and Authentication of Plant}

The plants were collected in and around Dharwad district in the month of June-2017 and were authentically identified as Centella asiatica Linn. belonging to the family Apiaceae by Dr. Satyanarayan. S.
Hebbar, Lecturer, Department of biology, Government P.U. College, Dharwad, Karnataka, India (SETCPD/ $\mathrm{REF} / 35 / 2017)$.

\subsection{Isolation of Endophytic Fungi from Centella asiatica}

The entire plant of Centella asiatica was washed thoroughly with distilled water and then they were surface sterilized with $90 \%$ ethanol followed by treatment with $4 \%$ sodium hypochlorite solution for 30 seconds to 1 minute and only the leaves were used for the study. For the preparation of culture media, petridish was collected and washed properly then it was rinsed with alcohol and left for drying. Two conical flasks of $250 \mathrm{ml}$ were taken and to it $4 \mathrm{gm}$ of Potato Dextrose Agar (PDA) and $25 \mathrm{mg}$ of streptomycin were added to each flask and they were dissolved in $100 \mathrm{ml}$ of distilled water in each flask. For proper solubility the flasks were kept in water bath for 5 minutes. The mouth of the flask was closed tightly. The petridish and the conical flask were collected and kept in an autoclave for moist heat sterilization for $1 \mathrm{hr}$. All the required materials were taken into laminar airflow chamber. The PDA solution were placed in petridish and left for 10 minutes to solidify. After the broth media is properly solidified then the plant parts were separately embedded in the media in 3 petridishes. The petridishes were closed with cover plate and kept in an incubator for further growth of endophytic fungi at $25-26^{\circ} \mathrm{C}$ for 7 days. After 7 days, growth of endophytes was noticed then it was subjected to subculture technique to get pure fungal $\operatorname{strain} \underline{21}-\underline{24}$.

\subsection{Subculturing Technique}

Broth media was prepared using PDA Petridish and PDA solution was sterilized by autoclaving for $120^{\circ} \mathrm{C}$ for 15-20 minutes. Small sections of grown endophytic fungi were transferred into media for proper growth. Transfer of endophytic fungi were done with flame sterilized inoculating loop by streaking and keeping in incubator at $25-26^{\circ} \mathrm{C}$ for 7 days. After incubation for 7 days the fungi were grown on the PDA solidified media and were sent for identification by PCR sequential analysis to Bhat biotech, Bengaluru ${ }^{25}$. Two samples were 
submitted for identification by colony morphology and compared with known organism from the literature.

\subsection{Fermentation of Isolated Fungi}

Fermentation of isolated fungi was carried out in 3 liters of PDB solution in Erlenmeyer flask and incubated at $25-26^{\circ} \mathrm{C}$ for 21 days under stationery condition. Fungal culture was filtered through four layers of cheese cloth and homogenized at $4000 \mathrm{rpm}$ to separate mycelia from broth.

\subsection{Extraction of Fungal Broth with Non- Polar Organic Solvents}

Extraction of fermented fungal broth was carried out using chloroform, ethyl acetate and n-butanol using separating funnel. The organic phase was separated to dryness under reduced pressure using rotary flash evaporator and weighed to constitute crude extract. All the crude fractions were weighed and calculated to know the $\%$ yield of each fraction. The $\%$ yield of chloroform, ethyl acetate and n-butanol fractions were found to be 4, 5 and 5.3gms respectively. Phytochemical screening and TLC studies of above endophytic fractions were carried out and it revealed the presence of alkaloids and steroids in chloroform fraction, tannins, flavonoids, volatile oils and coumarins in ethyl acetate fraction, carbohydrates, tannins flavonoids and volatile oils present in $n$-butanol fraction respectively $\underline{26}-\underline{28}$. Based on the results of phytochemical analysis and TLC studies, Isolation of steroid was carried out by gradient elution technique. And this was further characterized by I.R, NMR and Mass spectra. The chloroform, ethyl acetate and $\mathrm{n}$-butanol endophytic fungal fraction of Centella asiatica were further screened for invitro antioxidant activity.

\subsection{Isolation of Secondary Metabolite by Column Chromatography}

About $4 \mathrm{gm}$ of endophytic chloroform fraction of leaves of plant was chromatographed over silica gel, and elution was carried out from non-polar to polar solvents by gradient elution method.

1. Adsorbent - Silica gel (60-120 mesh).

2. Activation $-110^{\circ} \mathrm{C}$ for 1 hour.

3. Length of the column $-45 \mathrm{~cm}$.
4. Diameter - outer $4.5 \mathrm{~cm}$, inner $-2.5 \mathrm{~cm}$.

5. Length of the adsorbent $-30 \mathrm{~cm}$.

6. Rate of elution - 10-15 drops/min.

7. Volume of Elute collected $-10 \mathrm{ml}$ each.

8. Type of Elution - Gradient elution.

\subsection{Preparation of Sample}

$4 \mathrm{gm}$ of endophytic chloroform fraction of leaves of plant was dissolved in $20 \mathrm{ml}$ of methanol and mixed with 2 gm of silica gel (60-120 mesh) and dried in vacuum oven at $45{ }^{\circ} \mathrm{C}$. The material was transferred to the column.

\subsection{Column Packing}

Accurately weighed $100 \mathrm{gm}$ of silica gel was activated in hot air oven at $110^{\circ} \mathrm{C}$ for 1 hour. Column was washed with acetate and allowed to dry for half an hour and column was packed using wet packing method. Before packing glass wool was fixed properly at the bottom, the slurry of activated silica with petroleum ether was charged into the column in small proportion with gentle tapping after each addition in order to ensure the uniform packing. A small quantity of the solvent was allowed to remain at the top of the column in order to avoid the drying and cracking of the column. Tapping was done to avoid air bubble in the column during packing to avoid improper separation. The packed column was kept for stabilization overnight and column was run with Pet. ether to avoid impurities. Then the sample was charged into the packed column, a small cotton pad was kept over the topmost part of the column containing dust particles of the samples.

\subsection{Gradient Elution}

Gradient elution was carried out by using petroleum ether; Ethyl acetate, n-hexane: Ethyl acetate, petroleum ether: methanol and $100 \%$ methanol in different proportion. The elution rate was adjusted to $10-15 \mathrm{ml} /$ minute. Different fractions like 1-10, 11-20, 21-50, 5175, 76-100, 101-150, 151-200, 201-251, 251-275, 276$300,301-355$, and $356-375$ were eluted. T.L.C studies were carried out using pet ether and methanol $(7: 3)$ using vanillin $-\mathrm{H}_{2} \mathrm{SO}_{4}$ as spraying agent for all the fractions. Fraction 356-375 exhibited single spot on the TLC plate with Rf value 0.38 So fractions with similar 
spots in the range of 356-375 was pooled together and concentrated at reduced pressure and temperature. The component after drying revealed white crystalline powder.

\subsubsection{Phytochemical Test for Isolated Steroids}

- Salkowski test: Accurately weighed $1 \mathrm{mg}$ of isolated compound was dissolved in chloroform and few drops of concentrated sulphuric acid were added to the solution. Reddish colour was observed in chloroform layer indicating steroids are present.

- Liebermann-Burchard test: Accurately weighed $1 \mathrm{mg}$ of isolated compound was dissolved in chloroform and few drops of concentrated sulphuric acid were added to it, followed by the addition of 2-3 drops of acetic anhydride. Initially solution turned violet finally to green on further addition of acetic anhydride, indicating steroids are present.

\subsubsection{Spectral Characterization}

The structure of isolated compound -AP-1 was determined by IR, ${ }^{1} \mathrm{H}-\mathrm{NMR}$, Mass spectra and elemental analysis.

\subsubsection{Instruments Used}

The structure of isolated compound was confirmed by I.R. (Nicolet 5700, Thermo electron corporation, NMR (Bruker AV $300 \mathrm{Mhz}$ Spectrophoto meter). All spectra were recorded at $25{ }^{\circ} \mathrm{C}$ and the chemical shifts were recorded in $\partial$ PPM with the solvent shift. Deuterated chloroform $\left(\mathrm{CDCl}_{3}\right)$ and Dimethyl sulphoxide (DMSO) of HPLC grade were used as solvents. Electron ionization Mass spectrometry of the compound was performed by direct inlet at $70 \mathrm{ev}$ on the GCMS - QP 5050 (Schimadzu) spectrometer.

\subsubsection{In Vitro Free Radical Scavenging Activity}

1. Ferrous reducing antioxidant capacity assay (Reducing power assay)

The ferrous reducing antioxidant capacity (FRAC) of samples was evaluated by the method of Oyaizu ${ }^{29}$ The $\mathrm{Fe}^{2+}$ can be monitored by measuring the formation of Perl's Prussian blue at $700 \mathrm{~nm} .0 .25 \mathrm{~mL}$ samples/ standard solution at different concentration (50-450 $\mu \mathrm{g} / \mathrm{mL}), 0.625 \mathrm{~mL}$ of potassium buffer $(0.2 \mathrm{M})$ and $0.625 \mathrm{~mL}$ of $1 \%$ potassium ferricyanide, $\left[\mathrm{K}_{3} \mathrm{Fe}(\mathrm{CN})_{6}\right]$ solution was added into the test tubes. The reaction mixtures were incubated for $20 \mathrm{~min}$ at $50^{\circ} \mathrm{C}$ to complete the reaction. Then $0.625 \mathrm{~mL}$ of $10 \%$ trichloro acetic acid (TCA) solution was added into the test tubes. The total mixture was centrifuged at $3000 \mathrm{rpm}$ for $10 \mathrm{~min}$, after which $1.8 \mathrm{~mL}$ supernatant was withdrawn from the test tubes and mixed with $1.8 \mathrm{~mL}$ of distilled water and $0.36 \mathrm{~mL}$ of $0.1 \%$ ferric chloride $\left(\mathrm{FeCl}_{3}\right)$ solution. The absorbance of the solution was measured at $700 \mathrm{~nm}$ using a spectrophotometer against blank. A typical blank solution contained the same solution mixture without plant endophyte/standard and was incubated under the identical conditions. The absorbance of the blank solution was measured at $700 \mathrm{~nm}$. Ascorbic acid was used as standard. Increased absorbance of the reaction mixture indicates increased reducing capacity. The experiment was repeated three times at each concentration.

\subsubsection{DPPH Radical Scavenging Assay}

Free radical scavenging ability of the extracts was tested by DPPH radical scavenging assay as described by Blois and Desmarchelier et al. $\underline{30}, \underline{31}$ The hydrogen atom donating ability of the plant extractives was determined by the decolorization of methanol solution of 2,2-diphenyl-1-picrylhydrazyl (DPPH). DPPH produces violet/purple color in methanol solution and fades to shades of yellow color in the presence of antioxidants. A solution of $0.1 \mathrm{mM} \mathrm{DPPH}$ in methanol was prepared, and $2.4 \mathrm{~mL}$ of this solution was mixed with $1.6 \mathrm{~mL}$ of extract in methanol at different concentrations $(20-100 \mu \mathrm{g} / \mathrm{mL})$. The reaction mixture was vortexed thoroughly and left in the dark at RT for $30 \mathrm{~min}$. The absorbance of the mixture was measured spectro-photometrically at $517 \mathrm{~nm}$. Ascorbic acid was used as reference. Percentage DPPH radical scavenging activity was calculated by the following equation:

$\% \mathrm{DPPH}$ radical scavenging activity $=\left\{\left(\mathrm{A}_{0}-\mathrm{A}_{1}\right) / \mathrm{A}_{0}\right\} \times 100$

where $A_{0}$ is the absorbance of the control, and $A_{1}$ is the absorbance of the extractives/standard. Then $\%$ of inhibition was plotted against concentration, and from the graph $\mathrm{IC}_{50}$ was calculated. The experiment was repeated three times at each concentration. 


\subsubsection{Hydroxyl Radical Scavenging Activity}

Hydroxyl radical scavenging activity of the extractives was determined by the method of Halliwell et al. $\underline{32}, \underline{33}$ Hydroxyl radical was generated by the $\mathrm{Fe}^{3+}$-ascorbateEDTA- $\mathrm{H}_{2} \mathrm{O}_{2}$ system (Fenton reaction). The assay is based on the quantification of the 2-deoxy-d-ribose degradation product, which forms a pink chromogen upon heating with TBA at low $\mathrm{pH}$. The reaction mixture contained $0.8 \mathrm{~mL}$ of phosphate buffer solution (50 mmol L ${ }^{-1}, \mathrm{pH} 7.4$ ), $0.2 \mathrm{~mL}$ of endophytic extractives/ standard at different concentration $(100-500 \mu \mathrm{g} / \mathrm{mL})$, $0.2 \mathrm{~mL}$ of EDTA $\left(1.04 \mathrm{mmol} \mathrm{L}^{-1}\right), 0.2 \mathrm{~mL}$ of $\mathrm{FeCl}_{3}(1$ $\left.\mathrm{mmol} \mathrm{L}^{-1}\right)$ and $0.2 \mathrm{~mL}$ of 2-deoxy-d-ribose $(28 \mathrm{mmol}$ $\mathrm{L}^{-1}$ ). The mixtures were kept in a water bath at 37 ${ }^{\circ} \mathrm{C}$ and the reaction was started by adding $0.2 \mathrm{~mL}$ of ascorbic acid, $\mathrm{AA}\left(2 \mathrm{mmol} \mathrm{L}^{-1}\right)$ and $0.2 \mathrm{~mL}$ of $\mathrm{H}_{2} \mathrm{O}_{2}(10$ $\left.\mathrm{mmol} \mathrm{L}{ }^{-1}\right)$. After incubation at $37^{\circ} \mathrm{C}$ for $1 \mathrm{~h}, 1.5 \mathrm{~mL}$ of cold thiobarbituric acid, TBA $\left(10 \mathrm{~g} \mathrm{~L}^{-1}\right)$ was added to the reaction mixture followed by $1.5 \mathrm{~mL}$ of $\mathrm{HCl}(25 \%)$. The mixture was heated at $100{ }^{\circ} \mathrm{C}$ for $15 \mathrm{~min}$ and then cooled down with water. The absorbance of solution was measured at $532 \mathrm{~nm}$ with a spectrophotometer. The hydroxyl radical scavenging capacity was evaluated with the inhibition of percentage of 2-deoxy-d-ribose oxidation on hydroxyl radicals. Mannitol was used as standard. The percentage of hydroxyl radical scavenging activity was calculated according to the following formula: \% hydroxyl radical scavenging activity $=\left[\mathrm{A}_{0}\right.$ - $\left(A_{1}-A_{2}\right] \times 100 / A_{0}$ where $A_{0}$ is the absorbance of the control without a sample. $A_{1}$ is the absorbance after adding the sample and 2-deoxy-D-ribose. $\mathrm{A}_{2}$ is the absorbance of the sample without 2-deoxy-d-ribose. Then $\%$ of inhibition was plotted against concentration, and from the graph $\mathrm{IC}_{50}$ was calculated. The experiment was repeated three times at each concentration.

\subsubsection{Phytochemical Analysis}

Qualitative chemical analysis and thin layer chromatographic studies were carried out to detect important phytoconstituents present in endophytic leaf fractions of Centella asiatica.

\section{Results}

Isolation of Endophytic Fungi from Leaf of Centella asiatica

\section{- Phenotypic Identification}

The colonies grown on the agar plate were studied by the colony characteristics and lactophenol cotton blue staining. The characteristics were compared with the known organisms from the literature.

\section{- Colony Morphology}

The colonies grown on the agar plate were studied by the Lacto phenol cotton blue staining. The characteristics were compared with the known organisms from the literature.

\section{- Lacto Phenol Cotton Blue Staining}

Few drops of Lacto phenol cotton blue stain (HiMedia) was placed in the center of the clean glass slide. With a sterile cooled loop, the mycelia was transferred to the slide and teased gently. A clean cover slip was placed on it without air bubble. Using a blotting paper, the excess stain was removed. The slide was visualized under low to high power objectives of microscope.

\section{- Colony Morphology of Colletotrichum gloeosporioides}

Mycelium is septate, branched, hyaline and intercellular intracellular. Conidiophores are aseptate and cut into many unicellular, falcate, hyaline conidia, which, on germination, form the new mycelium (Figure 1).

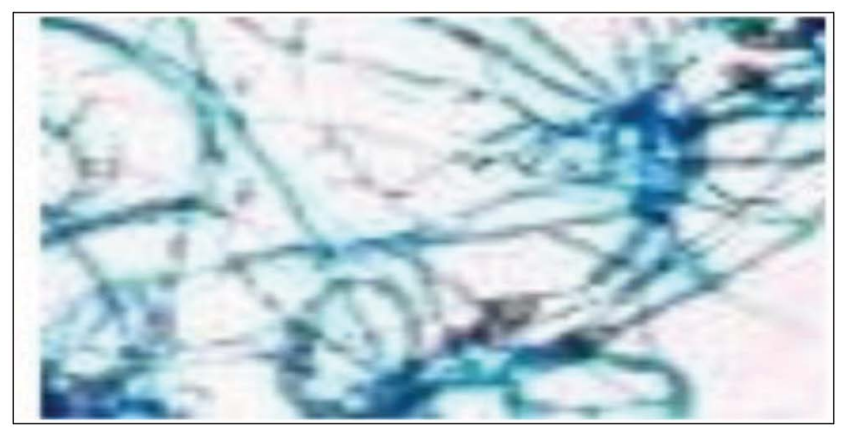

Figure 1. Lactophenol cotton blue-stain of the colonies observed on agar slant for CAL-1.

\section{- Colony Morphology of Penicillium}

The conidiophores are simple or branched and are terminated by clusters of flask-shaped phialides. The spores (conidia) are produced in dry chains from the tips of the phialides, with the youngest spore at the base of the chain, and are nearly brownish in colour. 
From the colony morphology and PCR sequential analysis, the above endophytic fungal samples were identified as Colletotrichum gloeosporioides and Pencillium species as shown in Figure 1 and 2.

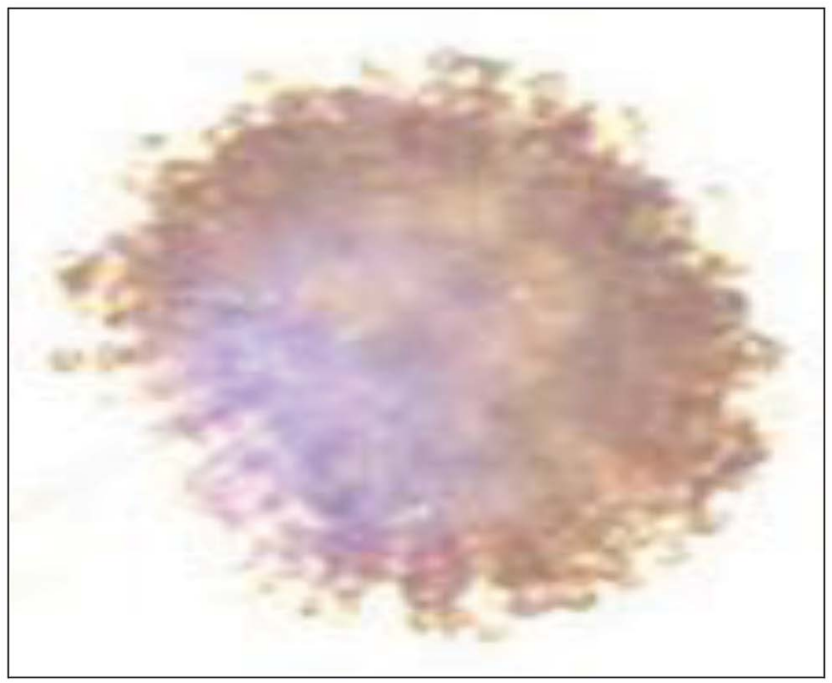

Figure 2. Lactophenol cotton blue-stain of the colonies observed on agar slant for CAR-2.

\section{- Physical Property of Isolated Compound}

Gradient elution of metabolite is shown in Table 1. Isolated compound (AP-1) appeared as white powder with melting point $158^{\circ}-160^{\circ} \mathrm{C}$. Molecular formula of the compound was found to be $\mathrm{C}_{29} \mathrm{H}_{48} \mathrm{O}$. The molecular weight of the compound was found to be 412.70 .

Spectral data (Figure 3)

$$
\begin{aligned}
& \text { IR (KBR) : } 3335 \mathrm{~cm}^{-1}(0 \mathrm{H}) \\
& \text { : } 2936 \mathrm{~cm}^{-1}\left(\mathrm{C}-\mathrm{H} \text { Stretching in } \mathrm{CH}_{3}\right) \\
& \text { : } 1453 \mathrm{~cm}^{-1}(\mathrm{C}=\mathrm{C} \text {, Streching }) \\
& \text { : } 1371 \mathrm{~cm}^{-1} \text { (C-O, Streching) } \\
& { }^{1} \mathrm{H}-\mathrm{NMR} \text {, (Coupling) } \\
& \text { (Figure 4) : } 1.39-1.48\left(\mathrm{~m}, 18 \mathrm{H}, 6 \times-\mathrm{CH}_{3}\right) \\
& \text { : } 1.61-1.9\left(\mathrm{~m}, 18 \mathrm{H}, 19 \times \mathrm{CH}_{2}\right) \\
& \text { : } \quad 2.0-2.64(\mathrm{~m}, 5 \mathrm{H} \text {, methine proton) } \\
& \text { : } 4.55 \text { (doublet, 1H,-OH, Secondary }
\end{aligned}
$$

\begin{tabular}{|c|c|c|c|c|c|}
\hline Fraction & Solvents and it's ratio & Colour of the elute & TLC solvents ratio & No. of spots with Rf. Values & Yield \\
\hline $1-10$ & Pet. Ether (1000ml) & Yellowish & $\begin{array}{l}\text { Pet. Ether methanol } \\
\qquad(7: 3)\end{array}$ & No spots & -- \\
\hline $11-20$ & $\begin{array}{l}\text { Pet. ether : ethyl acetate } \\
(75: 25)\end{array}$ & Yellowish brown & -- do -- & No spots & -- \\
\hline $21-50$ & $\begin{array}{l}\text { Pet. ether : ethyl acetate } \\
(50: 50)\end{array}$ & Yellowish brown & -- do -- & No spots & -- \\
\hline $51-75$ & $\begin{array}{l}\text { Pet. ether : ethyl acetate } \\
(25: 75)\end{array}$ & Yellowish brown & -- do -- & No spots & -- \\
\hline $76-100$ & $\begin{array}{l}\text { n-hexane: ethyl acetate } \\
(75: 25)\end{array}$ & No colour & -- do -- & No spots & -- \\
\hline $101-150$ & $\begin{array}{l}\text { n-hexane: ethyl acetate } \\
(50: 50)\end{array}$ & No colour & -- do -- & No spots & -- \\
\hline $151-200$ & $\begin{array}{l}\text { n-hexane: ethyl acetate } \\
(25: 75)\end{array}$ & No colour & -- do -- & No spots & -- \\
\hline $201-250$ & $\begin{array}{l}\text { Pet. ether: Methanol } \\
(75: 25)\end{array}$ & White & -- do -- & No spots & -- \\
\hline $251-275$ & $\begin{array}{l}\text { Pet. ether: Methanol } \\
\text { (50:50) }\end{array}$ & White & -- do -- & No spots & -- \\
\hline $276-300$ & $100 \%$ Methanol & White & -- do -- & No spots & --- \\
\hline $301-355$ & Methanol: $\mathrm{H}_{2} \mathrm{O}(75: 25)$ & white & -- do -- & No spots & ---- \\
\hline $356-375$ & Methanol: $\mathrm{H}_{2} \mathrm{O}(50: 50)$ & White ppt & -- do -- & Single spot 0.38 (AP-1) & $\begin{array}{l}200 \\
\mathrm{mg}\end{array}$ \\
\hline
\end{tabular}

Table 1. Gradient elution of metabolite from endophytic fraction of Centella asiatica 


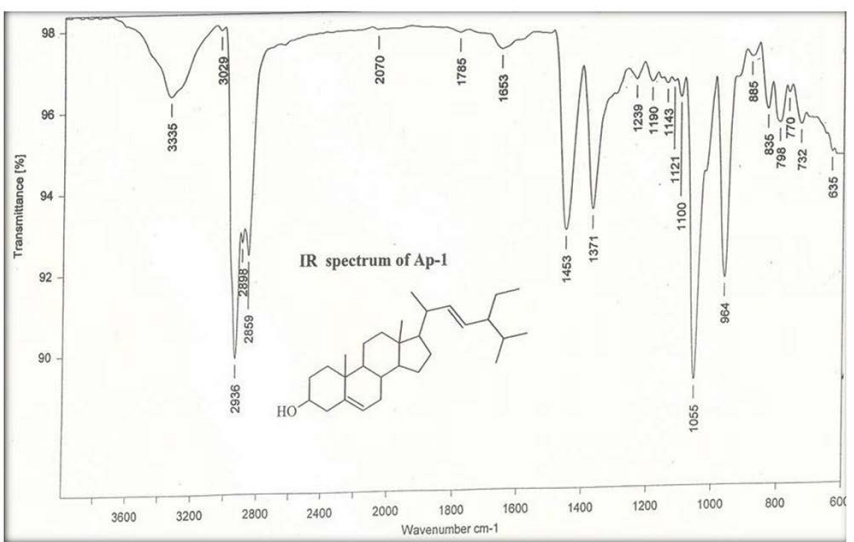

Figure 3. FTIR spectrum of isolated endophytic compound AP-1.

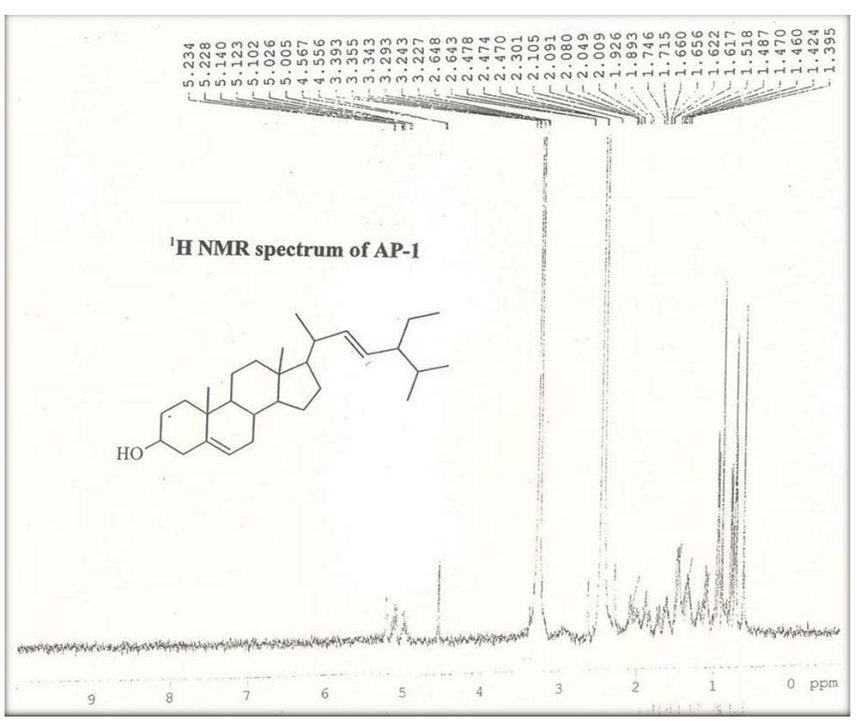

Figure 4. ${ }^{1} \mathrm{H}$ NMR spectrum of isolated endophytic compound AP-1.

\section{Mass spectra (EI-MS) (Figure 5)}

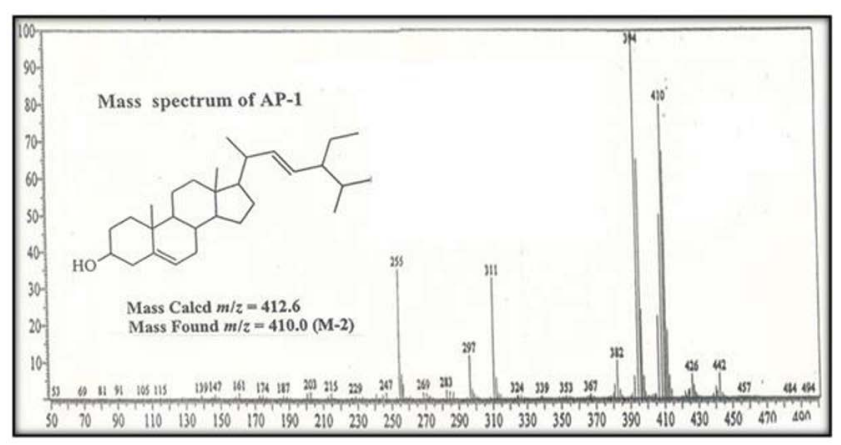

Figure 5. Mass spectrum of isolated endophytic compound AP-1.

$$
\begin{array}{lll}
\text { Molecular formula } & : & \mathrm{C} 29 \mathrm{H} 48 \mathrm{O} \\
\text { Molecular weight } & : & 412.70 \\
\text { Found }(\mathrm{m} / \mathrm{z}) & : & \mathrm{M}^{+},-410.00(\mathrm{M}-2)
\end{array}
$$

The FTIR, proton NMR and mass spectra are shown in Figure 3-5 respectively. From the above spectral data and comparison of this with the compound reported in the literature ${ }^{\frac{34}{}}$, the isolated compound AP-1 was confirmed as Stigmasterol.

\section{- PCR Sequential Analysis of Fungal Endophytes}

From the colony morphology and PCR sequential analysis, the above endophytic fungal samples (Figure 1) CAL-1 were identified as Colletotrichum gloeosporioides. The sample (Figure 2) CAR-2 were identified as Pencillium species respectively.

\section{- Phytochemical Analysis}

Preliminary phytochemical analysis and TLC studies of chloroform, ethyl acetate and n-butanol fraction of leaf of Centella asiatica revealed the presence of alkaloids and steroids in chloroform fraction, tannins, flavonoids and volatile oils in ethyl acetate and n-butanol fraction.

\section{- Isolation of Secondary Metabolite by Column Chromatography}

Based on the above spectral data I.R, N.M.R and mass spectra and on the available literature, the isolated endophytic compound of chloroform fungal fraction was identified as stigmasterol (Table 1 and Figure 3-5).

\section{- In vitro antioxidant activity}

Reducing power of endophytic extracts of Centella asiatica leaf (CAL-1) $(50-450 \mu \mathrm{g} / \mathrm{ml})$ increased with increase in concentration. The ethyl acetate extracts of CAL-1showed more effective reductive ability when compared to that of other extracts. In this assay, $\mathrm{Fe}$ (III) reduction is often used as a significant indicator of electron donating activity which is an important mechanism of phenolic antioxidant action by breaking the radical chain by donating a hydrogen atom. Here, the ethyl acetate extracts showed highest activity in a dose dependent manner (Table 2 and Figure 6).

Reaction with DPPH radicals of CAL-1 showed good scavenging activity. The $\mathrm{IC}_{50}$ values for Ascorbic acid, 
Table 2. Reducing power Assay for CAL-1 (Centella asiatica endophytic leaf extract)

\begin{tabular}{ccccc}
\hline $\begin{array}{c}\text { Concentration } \\
(\boldsymbol{\mu} \mathbf{g} / \mathbf{m l})\end{array}$ & Chloroform extract & Ethyl acetate extract & n-butanol extract & $\begin{array}{c}\text { Ascorbic Acid } \\
\text { (Standard) }\end{array}$ \\
\cline { 2 - 5 } & Absorbance & Absorbance & Absorbance & Absorbance \\
\hline 50 & 0.27 & 0.3 & 0.16 & 0.51 \\
100 & 0.28 & 0.32 & 0.22 & 0.59 \\
150 & 0.3 & 0.38 & 0.26 & 0.67 \\
200 & 0.28 & 0.48 & 0.34 & 0.78 \\
250 & 0.32 & 0.52 & 0.36 & 0.89 \\
300 & 0.33 & 0.58 & 0.41 & 0.97 \\
350 & 0.4 & 0.63 & 0.45 & 1.08 \\
400 & 0.54 & 0.64 & 0.57 & 1.19 \\
450 & 0.62 & 0.74 & 0.67 & 1.24 \\
\hline
\end{tabular}

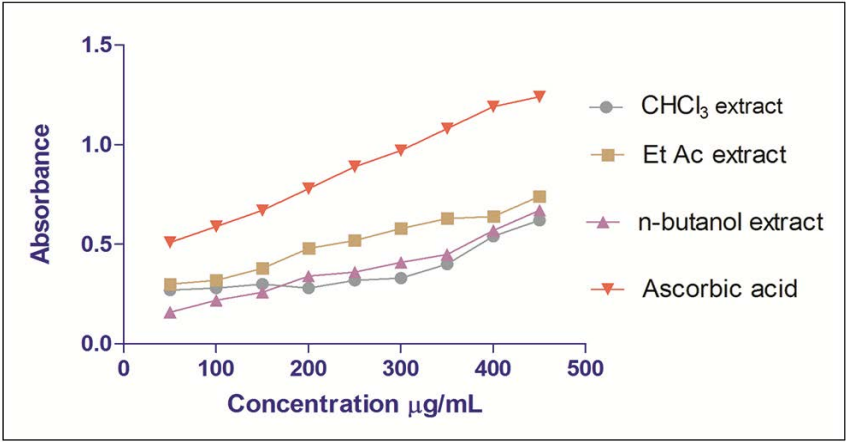

Figure 6. Reducing power Assay for CAL-1 (Centella asiatica endophytic leaf extract). chloroform extract, ethyl acetate extract and n- butanol extract were found to be $30.33 \mu \mathrm{g} / \mathrm{ml}, 66.58 \mu \mathrm{g} / \mathrm{ml}, 79.33$ $\mu \mathrm{g} / \mathrm{ml}$ and $96.39 \mu \mathrm{g} / \mathrm{ml}$ respectively. A linear correlation coefficient $\left(\mathrm{r}^{2}=0.9931,0.9947,0.9698\right)$ was obtained (Table 3 and Figure 7).

Activity of the ethyl acetate extract and $n$ butanol extract for CAL-1 exhibited concentration dependent scavenging activity against hydroxyl radial generated in a Fenton reaction system. This assay shows the abilities of the extract and standard mannitol to inhibit hydroxyl radical-mediated deoxyribose degradation in

Table 3. DPPH Assay for CAL-1 (Centella asiatica endophytic leaf extract)

\begin{tabular}{|c|c|c|c|c|c|}
\hline Standard & Ascorbic Acid & Sample & Chloroform extract & Ethyl acetate extract & n-butanol extract \\
\hline $\begin{array}{l}\text { Concentration } \\
(\mu \mathrm{g} / \mathrm{ml})\end{array}$ & $\begin{array}{c}\text { \% DPPH } \\
\text { Scavenging }\end{array}$ & $\begin{array}{l}\text { Concentration } \\
(\mu \mathrm{g} / \mathrm{ml})\end{array}$ & \% DPPH Scavenging & \% DPPH Scavenging & $\begin{array}{c}\text { \% DPPH } \\
\text { Scavenging }\end{array}$ \\
\hline 20 & 7.25 & 20 & 40.82 & 38.24 & 28.36 \\
\hline 40 & 29.54 & 40 & 45.37 & 43.41 & 32.24 \\
\hline 60 & 49.54 & 60 & 49.65 & 46.12 & 39.47 \\
\hline 80 & 70.15 & 80 & 53.26 & 50.13 & 42.35 \\
\hline \multirow[t]{6}{*}{100} & 90.14 & 100 & 55.33 & 53.25 & 47.38 \\
\hline & & 120 & 59.14 & 57.63 & 52.03 \\
\hline & & 140 & 63.91 & 61.85 & 65.21 \\
\hline & & 160 & 68.98 & 65.24 & 76.32 \\
\hline & & 180 & 72.74 & 71.84 & 79.25 \\
\hline & & 200 & 78.32 & 75.1 & 81.24 \\
\hline $\mathrm{IC}_{50}$ values & $30.33 \mu \mathrm{g} / \mathrm{ml}$ & $\mathrm{IC}_{50}$ values & $66.58 \mu \mathrm{g} / \mathrm{ml}$ & $79.33 \mu \mathrm{g} / \mathrm{ml}$ & $96.39 \mu \mathrm{g} / \mathrm{ml}$ \\
\hline $\mathrm{Y}=\mathrm{mX}+\mathrm{C}$ & $\begin{array}{l}y=1.9632 x- \\
11.876\end{array}$ & $\mathrm{Y}=\mathrm{mX}+\mathrm{C}$ & $y=0.2005 x+36.653$ & $y=0.2018 x+34.053$ & $y=0.322 x+18.969$ \\
\hline$r^{2}$ & 0.9991 & $r^{2}$ & 0.9931 & 0.9947 & 0.9698 \\
\hline
\end{tabular}




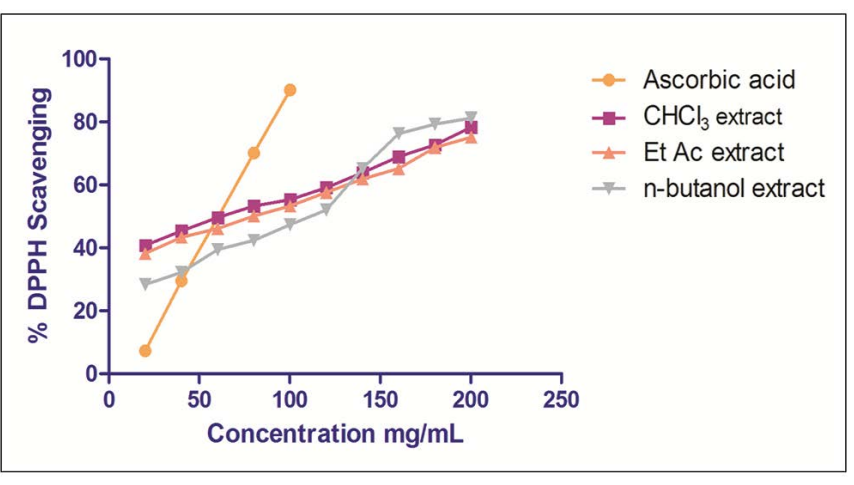

Figure 7. DPPH Assay for Centella asiatica endophytic leaf extract (CAL-1) and standard ascorbic acid. an $\mathrm{Fe}^{3+}$-EDTA-mannitol and $\mathrm{H}_{2} \mathrm{O}_{2}$ reaction mixture. The $\mathrm{IC}_{50}$ values for mannitol, chloroform extract, ethyl acetate extract and $\mathrm{n}$ butanol extract were found to be $121.06 \mu \mathrm{g} / \mathrm{ml}, 141.21 \mu \mathrm{g} / \mathrm{ml}, 181.80 \mu \mathrm{g} / \mathrm{ml}$ and 189.90 $\mu \mathrm{g} / \mathrm{ml}$ respectively (Table 4 and Figure 8 ).

\section{Discussion}

The plant Centella asiatica was collected in Dharwad district and authenticated by botanist Dr S.S Hebbar Department of botany, Govt science college, Dharwad and the herbarium specimen kept in the pharmacognosy

Table 4. Hydroxyl (-OH) scavenging assay for CAL-1 (Centella asiatica endophytic leaf extract)

\begin{tabular}{|c|c|c|c|c|}
\hline Standard & Mannitol & Chloroform extract & $\begin{array}{c}\text { Ethyl acetate } \\
\text { extract }\end{array}$ & n-butanol extract \\
\hline Concentration $(\mu \mathrm{g} / \mathrm{ml})$ & \% Hydroxyl Scavenging & $\begin{array}{l}\text { \% Hydroxyl } \\
\text { Scavenging }\end{array}$ & $\begin{array}{l}\text { \% Hydroxyl } \\
\text { Scavenging }\end{array}$ & \% Hydroxyl Scavenging \\
\hline 100 & 46.85 & 42.03 & 45.23 & 35.48 \\
\hline 200 & 55.21 & 53.58 & 56.28 & 54.25 \\
\hline 300 & 65.24 & 59.34 & 63.47 & 66.87 \\
\hline 400 & 69.32 & 65.36 & 71.58 & 73.58 \\
\hline 500 & 73.25 & 71.58 & 78.59 & 78.21 \\
\hline $\mathrm{IC}_{50}$ values & $121.06 \mu \mathrm{g} / \mathrm{ml}$ & $181.80 \mu \mathrm{g} / \mathrm{ml}$ & $141.21 \mu \mathrm{g} / \mathrm{ml}$ & $189.90 \mu \mathrm{g} / \mathrm{ml}$ \\
\hline $\mathrm{Y}=\mathrm{mX}+\mathrm{C}$ & $y=0.0669 x+41.901$ & $y=0.0709 x+37.114$ & $y=0.082 x+38.424$ & $y=0.1048 x+30.241$ \\
\hline$r^{2}$ & 0.9602 & 0.977 & 0.9925 & 0.9279 \\
\hline
\end{tabular}

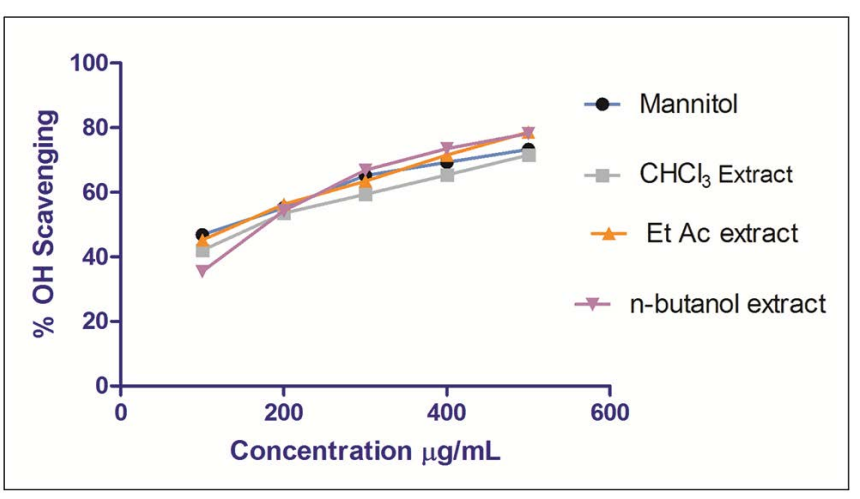

Figure 8. OH scavenging assay for CAL-1 (Centella asiatica endophytic leaf extract).
Department (SETCPD/REF/2017). Further isolation of endophytic fungi from leaves of the plant were carried out using Potato dextrose agar media followed by subculturing technique for a period of seven days to get a pure strain of fungi. Two fungal samples CAl-1 and CAR2 were sent to BHAT Biotech Pvt. Ltd., Electronic city, Bengaluru for colony morphology and PCR sequential analysis for fungal identification. From the colony morphology and PCR sequential analysis, the isolated endophytic fungal samples (Figure 1) CAL-1 were identified as Colletotrichum gloeosporioides, the sample (Figure 2) CAR-2 were identified as Pencillium species 
respectively. Fermentation of pure strains of isolated fungi were carried out in three liters of potato dextrose broth solution in Erlenmeyer flask and incubated at 25$26^{\circ} \mathrm{C}$ for 21 days and filtered to separate mycelia. Further extraction of fungal broth was carried out using non-polar organic solvents chloroform, ethyl acetate and n-butanol. The organic phase was dried and \% yield was found to be $4 \mathrm{gms}$, 5gms and 5.3gms respectively. Preliminary phytochemical analysis and TLC studies of chloroform, ethyl acetate and n-butanol fraction of leaf of Centella asiatica revealed the presence of alkaloids and steroids in chloroform fraction, tannins, flavonoids and volatile oils in ethyl acetate and n-butanol fraction. Sterol was isolated from chloroform fraction of endophytic fungi of leaves of Centella asiatica by column chromatography using gradient elution technique and were further confirmed by identification tests and spectral studies such as I.R, N.M.R and mass spectroscopy and were identified as stigmasterol as shown in (Figure 3-5). The ethyl acetate endophytic fractions of plant exhibited better antioxidant activity as compared to n-butanol fractions in all the tested invitro models. As there is proof those antioxidants may be useful in preventing the oxidative stress and protective biochemical functions of natural antioxidants present in the medicinal plants. It has been considered that polyphenols such as flavonoids and tannins show antioxidant property and their effect on human nutrition and health care are of considerable interest. The flavonoids are rich in donating the electrons, it has B-ring conjugated chemical structures with number of hydroxyl groups, which play important role by reacting with oxidative free radicals by hydrogenation $\underline{35}, \underline{36}$. Reducing power of endophytic extracts of Centella asiatica leaf (CAL-1) (50$450 \mu \mathrm{g} / \mathrm{ml}$ ) increased with increase in concentration. The ethyl acetate extracts of CAL-1 showed more effective reductive ability when compared to that of other extracts (Table 2). Reaction with DPPH radicals of CAL-1 showed good scavenging activity. The $\mathrm{IC}_{50}$ values for Ascorbic acid, chloroform extract, ethyl acetate extract and n- butanol extract were found to be $30.33 \mu \mathrm{g} / \mathrm{ml}, 66.58 \mu \mathrm{g} / \mathrm{ml}, 79.33$ $\mu \mathrm{g} / \mathrm{ml}$ and $96.39 \mu \mathrm{g} / \mathrm{ml}$ respectively (Table 3 ). Activity of the ethyl acetate extract and $n$ butanol extract for CAL1 exhibited concentration dependent scavenging activity against hydroxyl radial generated in a Fenton reaction system. The $\mathrm{IC}_{50}$ values for mannitol, chloroform extract, ethyl acetate extract and n- butanol extract were found to be $121.06 \mu \mathrm{g} / \mathrm{ml}, 141.21 \mu \mathrm{g} / \mathrm{ml}, 181.80 \mu \mathrm{g} / \mathrm{ml}$ and 189.90 $\mu \mathrm{g} / \mathrm{ml}$ respectively (Table 4 ). The endophytic ethyl acetate fraction exhibited prominent free radical scavenging activity in the all tested invitro models compared to other fractions. Therefore, there is need of potential antioxidants from natural source/endophytic community as an alternative to synthetic drugs for the prevention of deterioration of food, drugs and diseases which are caused by the liberation of free radicals.

\section{Conclusion}

In the present study, we observed that endophytic ethyl acetate leaf fractions of Centella asiatica exhibited potential antioxidant activity in all the invitro tested models. The activity may be due to presence of secondary metabolites such as tannins, flavonoids, coumarins, alkaloids and steroids in the endophytic fractions of Centella asiatica. Further investigations are needed to isolate and characterize the polyphenolic compounds which are present in the endophytic extracts including their mode of action in the management of oxidative stress caused by the free radicals.

\section{Acknowledgements}

The authors are thankful to the Rajiv Gandhi university of health sciences, Bengaluru, for granting the project (Ref no: RGU/ADV.RES/GRANTS/059/2016-17). Authors are also thankful to the President, Dr. Dambal HV and the Principal Dr. Kulkarni VH, SET's college of pharmacy, Dharwad, for providing the necessary facilities to carry out the research work.

\section{References}

1. Kunkel BA, Grewal PS, Quigley MF. A mechanism of acquired resistance against an entomopathogenic nematode by Agrotis ipsilon feeding on perennial ryegrass harboring a fungal endophyte. Biological Control. 2004; 29(1):100-08. https://doi.org/10.1016/S1049-9644(03)00119-1.

2. Shen L, Ye YH, Wang XT, Zhu HL, Xu C, Song YC, Li H, Tan RX. Structure and total $=$ synthesis of aspernigerin: a novel cytotoxic endophyte metabolite. Chemistry-A European Journal. 2006; 12(16):4393-96. https://doi.org/10.1002/ chem.200501423. PMid:16555343. 
3. Strobel GA. Rainforest endophytes and bioactive products. Critical Reviews in Biotechnology. 2002; 22(4):315-33. https:// doi.org/10.1080/07388550290789531. PMid:12487423.

4. Garai S, Mahato SB, Ohtani K, Yamasaki K. Bacopasaponin D-A Pseudojujubogenin glycoside from Bacopa monniera. Phytochemistry. 1996; 43(2):447. https://doi. org/10.1016/0031-9422(96)00250-6.

5. Singh HK. and Dhavan B.N. Preclinical Neuropsycho pharmacological Investigations on Bacosides: A Nootropic Memory Enhancer (Abs. T-3:3),Central Drug Reasearch Institute, Luknow, 1996, P-65.

6. Zheng CJ, Qin LP. Chemical components of Centella asiatica and their bioactivities. Phytochemistry. 2007; 5(3):348-51. https://doi.org/10.3736/jcim20070324. PMid:17498500.

7. Devi NN, Prabakaran JJ. Bioactive metabolites from an endophytic fungus Penicillium sp. isolated from Centella asiatica. Curr. Res. Environ Appl. Mycol. 2014; 4(1):34-43. https://doi.org/10.5943/cream/4/1/3.

8. Gawas P, Shenoy BD, Hyde KD, Bhat DJ. Echinosphaeria macrospora sp. nov. Teleomorph of Vermiculariopsiella Endophytica sp. nov. 2006; 27:11-20.

9. Krishnamurthy YL, Naik SB, Jayaram S. Fungal communities in herbaceous medicinal plants from the Malnad region, Southern India. Microbes and Environments. 2008; 23(1):2448. https://doi.org/10.1264/jsme2.23.24. PMid:21558683.

10. Satheesan J, Narayanan AK, Sakunthala M. Induction of root colonization by Piriformospora indica leads to enhanced asiaticoside production in Centella asiatica. Mycorrhiza. 2012; 22(3):195-202. https://doi.org/10.1007/s00572-011-0394-y. PMid:21688071.

11. Rafat A, Philip K, Muniandy S. A novel source of bioactive compounds: endophytic bacteria isolated from Centella asiatica. J. Pure. Appl. Microbiol. 2012; 6(1):11-20.

12. Rakotoniriana EF, Rafamantanana M, Randriamampionona D, Rabemanantsoa C, Urveg-Ratsimamanga S, El Jaziri M, Munaut F, Corbisier AM, Quetin-Leclercq J, Declerck S. Study in vitro of the impact of endophytic bacteria isolated from Centella asiatica on the disease incidence caused by the hemibiotrophic fungus Colletotrichum higginsianum. Antonie Van Leeuwenhoek. 2013; 103(1):121-33. https://doi. org/10.1007/s10482-012-9791-2. PMid:22903452.

13. Nath A, Pathak J, Joshi SR. Bioactivity assessment of endophytic fungi associated with Centella asiatica and Murraya koengii. Journal of Applied Biology and Biotechnology. 2014; 2(05):006-11.

14. Prabakaran NN, Femina W. Antibiogram pattern of enhopityc fungi isolated from medical plant Centella asiatica. Journal of Pharmacy Research. 2012; 5:205-07.

15. Veerendra Kumar MH, Gupta YK. Effect of Centella asiatica on cognition and oxidative stress in an intracerebroventricular streptozotocin model of Alzheimer's disease in rats. Clinical and Experimental Pharmacology and Physiology. 2003; 30(5):336-42. https://doi.org/10.1046/ j.1440-1681.2003.03842.x. PMid:12859423.

16. Xu Y, Cao Z, Khan I, Luo Y. Gotu Kola (Centella asiatica) extract enhances phosphorylation of cyclic AMP response element binding protein in neuroblastoma cells expressing amyloid beta peptide. Journal of Alzheimer's Disease. 2008; 13(3):341-49. https://doi.org/10.3233/JAD-2008-13311. PMid:18431001.

17. Jayashree G, Muraleedhara GK, Sudarslal S, Jacob VB. Anti-oxidant activity of Centella asiatica on lymphoma-bearing mice. Fitoterapia. 2003; 74(5):431-34. https://doi.org/10.1016/S0367-326X(03)00121-7.

18. Ernawati M, Solihin DD, Lestari YU. Community structures of endophytic actinobacteria from medicinal plant Centella asiatica L. urban-based on metagenomic approach. Int. J. Pharm Pharm Sci. 2016; 8:292-97.

19. Nongkhlaw FM, Joshi SR. Micrographical assessment of antifungal effect of endophytic bacteria. Proceedings of the National Academy of Sciences, India Section B: Biological Sciences. 2016; 86(1):9-14. https://doi.org/10.1007/s40011014-0321-z.

20. Heidari M, Jamshedi AH, Akhondzadeh SH, Ghaffari NM, Sadeghi MR, Khansari GM, et al. Evaluating the effects of Centella asiatica on spermatogenesis in rats. Med. J. Reprod. Infertility. 2007; 7:367-74.

21. Wiyakrutta S, Sriubolmas N, Panphut W, Thongon N, Danwisetkanjana K, Ruangrungsi N, Meevootisom V. Endophytic fungi with anti-microbial, anti-cancer and antimalarial activities isolated from Thai medicinal plants. World journal of microbiology and biotechnology. 2004; 20(3):26572. https://doi.org/10.1023/B:WIBI.0000023832.27679.a8.

22. Silva GH, Teles HL, Trevisan HC, Bolzani VD, Young M, Pfenning LH, Eberlin MN, Haddad R, Costa-Neto CM, Araújo ÂR. New bioactive metabolites produced by Phomopsis cassiae, an endophytic fungus in Cassia spectabilis. Journal of the Brazilian Chemical Society. 2005; 16(6B):146366. https://doi.org/10.1590/S0103-50532005000800029.

23. Tejasvi MV, Kini KR, Prakash HS, Subbiah V, Shetty HS. Antioxidant, antihypertensive and antibacterial properties of endophytic pestalotiopsis species from medicinal plants. Can. J. Microbiol. 2008; 54:769-80. https://doi.org/10.1139/ W08-070. PMid:18772940.

24. Shukla ST, Kulkarni VH, Habbu PV, Jagadeesh KS, Patil BS, Smita DM. Hepatoprotective and antioxidant activities of crude fractions of endophytic fungi of Ocimum sanctum Linn. in rats. Oriental Pharmacy and Experimental Medicine. 2012; 12(2):81-91. https://doi.org/10.1007/s13596-012-00617.

25. Doty SL, Dosher MR, Singleton GL, Moore AL, Van Aken B, Stettler RF, Strand SE, Gordon MP. Identification of an endophytic Rhizobium in stems of Populus. Symbiosis. 2005; 39(1):27-35. 
26. Sharma BJ. Thin layer chromatography, 2nd Edn., INC, New York; 1986. p. 119.

27. Staul E. Thin layer chromatography, 2nd Edn., Heidelburg, Newyork; 1990. p. 362.

28. Wagner H, Bladet S. Plant drug analysis, Heidelburg, 2nd Edn., Newyork; 1994. p. 192.

29. Doty SL, Dosher MR, Singleton GL, Moore AL, Van Aken B, Stettler RF, Strand SE, Gordon MP. Identification of an endophytic Rhizobium in stems of Populus. Symbiosis. 2005; 39(1):27-35.

30. Wiyakrutta S, Sriubolmas N, Panphut W, Thongon N, Danwisetkanjana K, Ruangrungsi N, Meevootisom V. Endophytic fungi with anti-microbial, anti-cancer and antimalarial activities isolated from Thai medicinal plants. World Journal of Microbiology and Biotechnology. 2004; 20(3):26572. https://doi.org/10.1023/B:WIBI.0000023832.27679.a8.

31. Silva GH, Teles HL, Trevisan HC, Bolzani VD, Young M, Pfenning LH, Eberlin MN, Haddad R, Costa-Neto CM, Araújo ÂR. New bioactive metabolites produced by Phomopsis cassiae, an endophytic fungus in Cassia spectabilis. Journal of the Brazilian Chemical Society. 2005; 16(6B):146366. https://doi.org/10.1590/S0103-50532005000800029.
32. Tejasvi MV, Kini KR, Prakash HS, Subbiah V, Shetty HS. Antioxidant, antihypertensive and antibacterial properties of endophytic pestalotiopsis species from medicinal plants. Can J. Microbiol. 2008; 54:769-80. https://doi.org/10.1139/W08070. PMid:18772940.

33. Shukla ST, Kulkarni VH, Habbu PV, Jagadeesh KS, Patil BS, Smita DM. Hepatoprotective and antioxidant activities of crude fractions of endophytic fungi of Ocimum sanctum Linn. in rats. Oriental Pharmacy and Experimental Medicine. 2012; 12(2):81-91. https://doi.org/10.1007/s13596-012-0061-7.

34. Kashmira JG, Jagruti AP and Anuradha KG. Pharmacological review on Centella asiatica: A potential herbal cure. Indian. J. PharmaSci.2010;75(5):546-56.https://doi.org/10.4103/0250474X.78519. PMid:21694984, PMCid:PMC3116297.

35. Choudary N, Bijem KR, Kalia AN. Antiepileptic potential of flavonoids fraction from the leaves of Anisomeles malabarica. Journal of Ethanopharmacology, 2011; 135(2):238-42. https://doi.org/10.1016/j.jep.2011.02.019. PMid:21354295.

36. Shastry RA, Smita D. Madagundi, Prasanna V. Habbu et al. Phytochemical investigation and antiepileptic activity of Aspergus racemosus(Wild) root extracts in rodents. RGUHS J. Pharm Sci. 2015; 5(3):97-103. https://doi.org/10.5530/ rjps.2015.3.3. 